Acta Theriologica 41 (2): 155-170, 1996.

PL ISSN 0001-7051

\title{
Winter distribution and abundance of mustelids and beavers in the river valleys of Białowieża Primeval Forest
}

\author{
Vadim E. SIDOROVICH, Bogumiła JĘDRZEJEWSKA \\ and Włodzimierz JĘDRZEJEWSKI
}

Sidorovich V. E., Jędrzejewska B. and Jędrzejewski W. 1996. Winter distribution and abundance of mustelids and beavers in the river valleys of Białowieża Primeval Forest. Acta Theriologica 41: $155-170$.

Lutra lutra, Mustela vison, $M$. putorius, $M$. erminea, $M$. nivalis, and the settlements of Castor fiber were surveyed along $170 \mathrm{~km}$ of rivers in Białowieża Primeval Forest (Poland and Belarus), the best preserved temperate lowland forest in Europe. The censused rivers varied from very small $(1-5 \mathrm{~m}$ wide, $<1 \mathrm{~m}$ deep) to medium-sized (11-15 $\mathrm{m}$ wide, up to $3 \mathrm{~m}$ deep). Mustelids were counted by tracks left in snow. Mean index of abundance of otters was 2.2 inds $/ 10 \mathrm{~km}$ of the river bank (range 0-5) and that of mink 4.6 inds $/ 10 \mathrm{~km}$ (range $0-7.5$ ). On average, 1.4 polecats $/ 10 \mathrm{~km}$ were recorded (range $0-5$ ). Otters and mink were most abundant on the medium-sized rivers and least numerous on very small ones. Polecats lived predominantly on very small rivers. Species structure of a predator guild varied with river size. On average, 5.1 stoats and 4.0 weasels were counted per $10 \mathrm{~km}$ of river bank. Stoats were twice as common along rivers with open marshy flood-plain as along rivers with forested valleys. On average, 2.9 beaver settlements were recorded per $10 \mathrm{~km}$ of river bank (range $0-5$ ). Habitat niche overlaps were highest between otter and mink, and stoat and mink. The smallest overlaps were between the polecat and all other predators. Densities of mustelid predators and beavers in Białowieża Primeval Forest were similar to those in other fairly well preserved woodlands in Europe.

Institute of Zoology, Belarussian Academy of Sciences, F. Skoriny 27, Minsk 220072, Belarus (VES); Workshop for Ecology and Protection of the Natural Environment, 17-230 Białowieża, Poland (BJ); Mammal Research Institute, Polish Academy of Sciences, 17-230 Białowieża, Poland (WJ)

Key words: otter, American mink, polecat, stoat, weasel, beaver, habitat niches, Białowieża Forest

\section{Introduction}

In the temperate zone of Europe, the fauna of rivers and inland water bodies has for a long time been heavily transformed, and often devastated. Over large areas, small and large rivers are drained or canalised, natural flood plains are converted into stabilised meadows and fields. Across central and eastern Europe, in some regions, well preserved large-scale river systems still exist in lowlands. Originally, in the primeval habitats of mixed and deciduous temperate forests and natural open marshes, the guild of mustelids consisted of the river otter, the 
European mink, and the polecat. At present, the European mink survives in north-eastern Europe (Belarus, Russia, Estonia; Tumanov and Zverev 1986, Maran 1990, Sidorovich and Kozulin 1994) and in western Europe (Spain and France; Saint-Girons 1991). In the 20th century, the American mink from both deliberate introductions and from fur-farm escapes has been spreading rapidly (Pucek 1984).

The beaver, once a common inhabitant and a major agent of natural water 'engineering', had become extinct from most of temperate Europe (Pucek 1984, Görner and Hackethal 1988). Recently, it has been successfully reintroduced in Poland (Żurowski 1979, Żurowski and Kasperczyk 1988) and recovers in other countries of Europe.

A study conducted in Belarus (Pikulik and Sidorovich 1991) indicated that the functioning of the semiaquatic predator-prey system differs greatly from those in the forests and open areas such as meadows and farmlands (Goszczyński 1977, Jędrzejewski and Jędrzejewska 1993). While numerous works are done on the diet composition of the otter, polecat, and mink in Europe (eg Dunstone and Birks 1987, Weber 1989, Kruuk and Moorehouse 1990) and the large scale distribution of these predators (eg Pucek and Raczyński 1983), the community approach has rarely been applied.

In this paper, we present the results of a census of predatory mammals [river otter Lutra lutra (Linnaeus, 1758), American mink Mustela vison Schreber, 1777, polecat Mustela putorius Linnaeus, 1758, stoat Mustela erminea Linnaeus, 1758, weasel Mustela nivalis Linnaeus, 1766] and beaver Castor fiber Linnaeus, 1758, inhabiting river valleys in Białowieża Primeval Forest. We aimed at showing (1) abundance, species and dominance structure of the guild of mustelid predators on various size rivers; (2) relationships between habitat structure (river type and size) and occurrence of a given species of predator; (3) habitat niche separation of predators in the river valleys; and (4) densities of beaver settlements.

This study, a result of cooperation between the Polish and the Belarussian Academies of Sciences, has been one of the first zoological surveys that covered both parts (Polish and Belarussian) of Białowieża Primeval Forest in the recent time.

\section{Study area}

Białowieża Primeval Forest (BPF, $52^{\circ} 30^{\prime}-53^{\circ} \mathrm{N}, 23^{\circ} 30^{\prime}-24^{\circ} 15^{\prime} \mathrm{E}$ ), located on the Polish-Belarussian border, is a vast woodland connected by continuous forests with other large forest tracts (Pruzhana Forest in NE, Shereshevo Forest in SE, Knyszyn Forest in NW). It lies in the boreal nemoral zone, and is composed of rich multispecies tree stands. In its historical borders, BPF covers $1250 \mathrm{~km}^{2}$, but in the recent decades its administrative coverage increased to $1450 \mathrm{~km}^{2}$ due to amendance (in both Polish and Belarussian parts) of peripheral woods and woodlots, mostly of secondary origin.

The Polish part of BPF $\left(580 \mathrm{~km}^{2}\right.$, see Fig. 1) includes Białowieża National Park (BNP, $\left.47.5 \mathrm{~km}^{2}\right)$ and the exploited forests administered by the State Forestry $\left(530 \mathrm{~km}^{2}\right)$. BNP is a strict reservation where no hunting, timber exploitation or motor transportation is allowed. In the 1970 s the Park 
became one of UNESCO's Man \& Biosphere Reserves and World Heritage Sites. The exploited forests on the Polish side of the border are managed by means of small clear cuts and selective cutting of large trees, and replantation. In the Belarussian part of BPF $\left(870 \mathrm{~km}^{2}\right)$, cutting is small and selective (dead and dying trees only, no clearcuts). In 1991, the whole Belarussian part of BPF became the State National Park (with some strict reserves but mostly a partial protection regime) and a UNESCO's Man \& Biosphere Reserve.

The forests of BPF are composed of oak Quercus robur, hornbeam Carpinus betulus, pine Pinus silvestris, spruce Picea abies, black alder Alnus glutinosa, ash Fraxinus excelsior, lime Tilia cordata, maple Acer platanoides, birches Betula verrucosa and B. pubescens and several other tree species. More detailed information about vegetation of BPF is given by Faliński (1986).

The altitude of BPF varies from 134 to $202 \mathrm{~m}$ a.s.l. The rivers in the northern part of BPF are tributaries of the Narew river, and in the southern part are tributaries of the Bug river. Both the Narew and the Bug are affluents of the Vistula river (Baltic sea basin). In the flat terrain of BPF, the slope of the rivers is from $0.35 \mathrm{~m} / \mathrm{km}$ (Narewka river) to $0.64 \mathrm{~m} / \mathrm{km}$ (Leśna river). Few man-made water bodies are located in BPF (Fig. 1): two small ponds on the Narewka river (constructed in the 18th century), a pond for timber storage on the Perebel river (built in the 1930s), and two reservoirs on the Perevoloka river (built in the 1960s). A large water retention reservoir on the Narew river (completed in the late 1980s) is located north of BPF. Only the reservoirs on Perevoloka were surveyed.

Some amelioration works (eg on the Narewka river) were carried out as early as the 18th century, but most of rivers remain natural. Of the censused rivers, only the Leśna suffers from industrial pollution, from the town of Hajnówka, but some dilution of sewage occurs in the course of the river. In the Polish four-grade scale of river cleanness (class 1 being unpolluted rivers), the whole Leśna is classified to grades 3 or 4 . The Narewka is polluted by household sewage around Białowieża village (grade 4), but it is clean (grade 1) on the whole remaining lengths. All other rivers receive very little sewage, if any at all (class 1) (E. Malzahn and W. Miniuk, unpubl.).

The flood-plain valleys of all the medium-sized and small rivers (and a part of the Łutownia river) have for centuries been used as meadows. This practise has created grassland areas up to $1 \mathrm{~km}$ wide (with sparse willow and alder trees) along the rivers. In the Polish part of BPF mowing was abandoned in the recent decades, and the valleys undergo secondary forest succession. Now, they are dominated by tall forb and sedge meadows, reeds and willow bushes. The smallest rivers flow through forests (ash-alder flood-plain forests).

\section{Material and methods}

In all, 170 kilometres of rivers, ie about $75 \%$ of their total length, were surveyed (Fig. 1). We classified the censused rivers as: (1) medium-sized rivers (Narew, Leśna, lower course of Narewka, 11-15 m wide and about 1.5-3 m deep); (2) small rivers (upper course of Narewka, Belaya, Hwoźna, Perevoloka, 6-10 m wide and 1-2 m deep); and (3) very small rivers (Łutownia, Rudavka, Orłówka, Braszcza, 1-5 m wide and $<1 \mathrm{~m}$ deep). Some stretches of the very small rivers dry out in hot summers.

The survey was conducted in February-March 1994. Each stretch was surveyed once. Smaller rivers were walked, whereas the bigger ones were canoed. Banks of rivers were searched for foot prints and other signs of activity of river otters, American mink, and polecats left on snow and mud. Fresh tracks of specimens (or family groups) usually formed concentrations along the river, separated by various length distances with no tracks. We aimed at counting the number of individuals living on the surveyed stretches of rivers. To do this, we applied the following criteria. In otters, the prints of hind foot were measured to estimate the age of an individual. According to the methodological work by Sidorovich (1992a), prints of hind foot are 4-6 cm long in juvenile otters (< 1 year old), and 7.9-12 $\mathrm{cm}$ in adults ( $>2$ years old). Subadults (1-2 years old) have tracks intermediate in size, and the range 


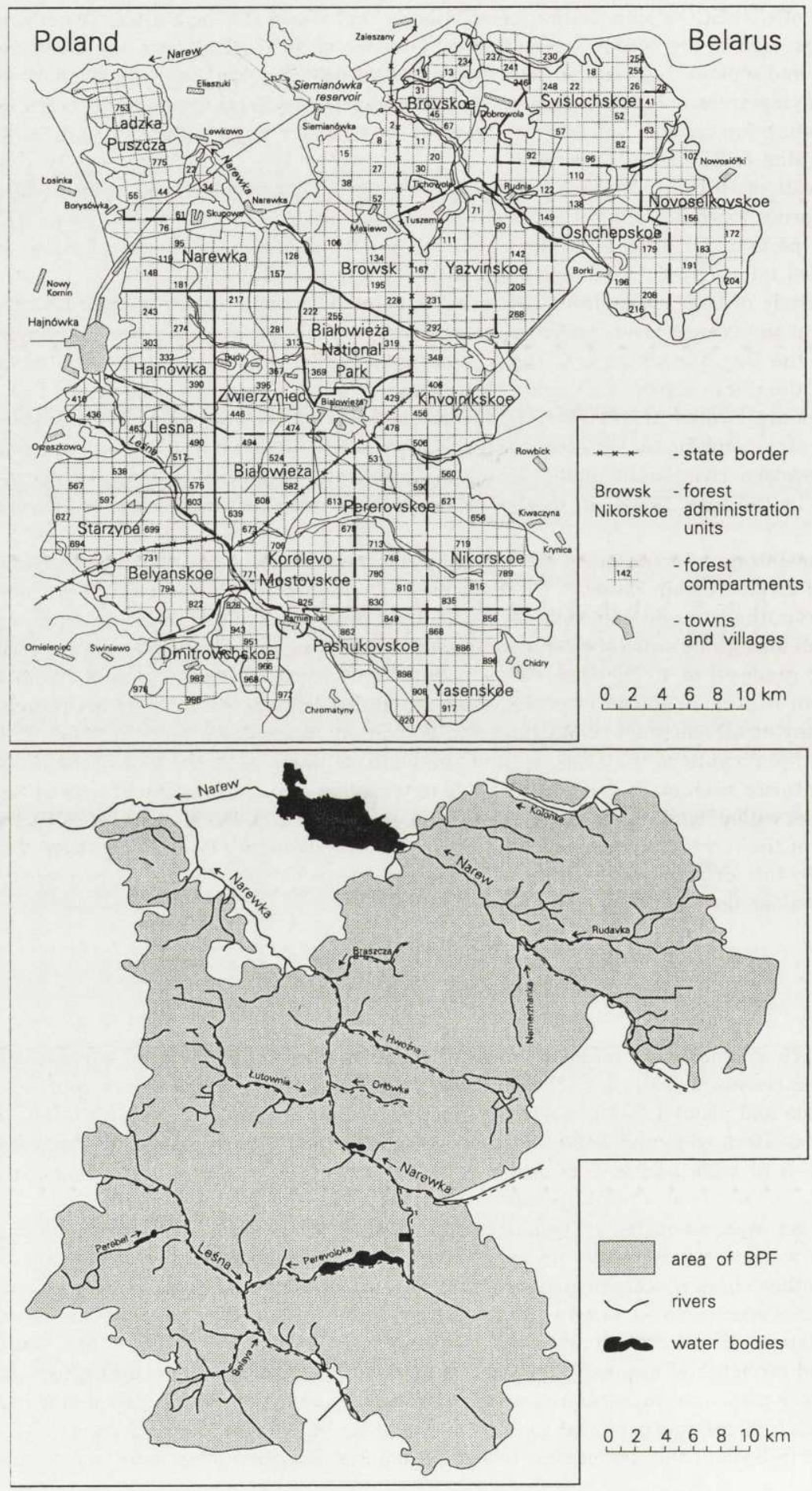


of measurements overlaps with those for kittens and adults. Statistical analysis done by Sidorovich (1992a) showed that the error of ageing of individuals due to that overlap is $2 \%$. In our field survey, differences in measurements of foot prints of single otters consistently $>1 \mathrm{~cm}$ were accepted as criterion for differentiating individuals. Family groups, ie adult female with young, were distinguished from lone individuals (cf Erlinge 1967). In the case of single otters, fresh marking places (with urine and faeces) were searched for to determine the sex. In relation to prints of hind feet, males leave urine marks on snow in front of a scat, whereas females defecate scat and urine in the same place or urine marks are sprinkled behind the scat.

American mink and polecats were surveyed by foot prints. The sets of identification characters for each species (with illustrations) are shown in the methodological paper by Sidorovich (1994). Wherever possible, the sex of individuals was determined by signs of urine marking (criteria, resulting from anatomical differences between sexes, as for otters). In differentiating individual polecats and minks, beside the sex, an auxiliary feature was track size (not measured but assessed visually).

Stoats and weasels were recorded by tracking in snow, on some rivers only, on a land transect close to the water course. Foot prints of stoats (beside being distinctly larger) are acute-angled on top, whereas those of weasels are rounded. Visually assessing size of tracks and pace length was an auxiliary feature in counting individual stoats and weasels.

Beaver settlements were registered by freshly gnawed trees and bushes by the river, dams built on a river, and lodges and burrows in the river banks. All records were put down on a map. Weather conditions during the surveys (relatively mild winter, rivers mostly not frozen, frequent snowfalls that melted quickly) made it possible to register only the fresh tracks of predators.

In the described method of surveying mustelids by their tracks, a critical factor is the expertise and experience of a tracking person. In this research, the field survey was done by V. E. Sidorovich, who has a several-year practise in snowtracking semiaquatic mustelids in Belarus, and, in various circumstances, had verified the results of snowtracking by later trapping on the same river stretches. In this research, in the case of polecats and weasels, we could compare the results of the snowtracking survey with data obtained by other methods (live-trapping, radio-telemetry), and we found very good correspondence between the two estimates (details in Discussion). Nonethelees, we are aware that the results of our surveys are indices of abundance on various size rivers and cannot be treated as absolute numbers or densities.

\section{Results}

\section{Abundance of mustelid predators and beaver settlements}

Abundance of river otters varied from 0 to 5.0 individuals per $10 \mathrm{~km}$ of the water course, and were on average 2.2 inds $/ 10 \mathrm{~km}$ (Table 1). Otters were most numerous on the medium-sized rivers and least numerous on very small ones (Fig. 2). Mean abundance index of American mink was 4.6 inds $/ 10 \mathrm{~km}$ of the censused rivers. The mink showed the same trend of occurrence as the otter; the highest numbers were recorded on the medium-sized rivers (up to 7.5 inds/10 km on the Leśna river) and low on very small ones (Table 1, Fig. 2). In contrast, polecats were most abundant on very small rivers (up to 5 inds/10 $\mathrm{km}$ on the Orłówka river) and rare on the medium-sized ones (Fig. 2). The average index of abundance of polecats was $1.4 \mathrm{inds} / 10 \mathrm{~km}$ of the water course (Table 1).

$\leftarrow$ Fig. 1. Upper panel: administrative map of Białowieża Primeval Forest. Lower panel: rivers and other water bodies in BPF. The censused rivers are marked with broken lines. 
Table 1. Winter abundance indices of mammalian predators and beaver settlements on rivers in Białowieża Primeval Forest. Numbers of recorded individuals (or settlements in the case of beavers) are given in parentheses. Abundance index in $n$ inds $/ 10 \mathrm{~km}$ of the river ( $n$ settlements $/ 10 \mathrm{~km}$ in beavers). Rivers are listed in the order of decreasing size: medium-sized rivers - Narew, Leśna, lower Narewka; small rivers - upper Narewka, Belaya, Hwoźna, Perevoloka; very small rivers - Łutownia, Rudavka, Orłówka, Braszcza. ? - no data. ${ }^{a}$ surveyed were also two water reservoirs on the Perevoloka river and 5.5-km stretch of the Pererovnica river (see Fig. 1). ${ }^{b}$ total lengths of rivers, on which stoats and weasels were surveyed.

\begin{tabular}{|c|c|c|c|c|c|c|c|}
\hline River & $\begin{array}{l}\text { Length } \\
\text { censused } \\
(\mathrm{km})\end{array}$ & Otter & $\begin{array}{l}\text { American } \\
\text { mink }\end{array}$ & Polecat & Stoat & Weasel & $\begin{array}{l}\text { Beaver } \\
\text { settle- } \\
\text { ments }\end{array}$ \\
\hline Narew (lower) & 14 & (5) 3.6 & (8) 5.7 & (1) 0.7 & $?$ & $?$ & (4) 2.9 \\
\hline Narew (upper) & 17 & (4) 2.3 & (10) 5.9 & (2) 1.2 & $?$ & $?$ & (5) 2.9 \\
\hline Leśna (lower) & 12 & (3) 2.5 & (8) 6.7 & (2) 1.7 & (7) 5.8 & (9) 7.5 & (6) 5.0 \\
\hline Leśna (upper) & 16 & (2) 1.3 & (12) 7.5 & (0) 0 & (11) 6.9 & (2) 1.3 & (7) 4.4 \\
\hline Narewka (lower) & 20 & (10) 5.0 & (12) 6.0 & (2) 1.0 & (12) 6.0 & (7) 3.5 & (9) 4.5 \\
\hline Narewka (upper) & 8 & (1.5) 1.9 & (2) 2.5 & (1) 1.3 & $?$ & $?$ & (1) 1.3 \\
\hline Belaya & 8 & (1) 1.3 & (2) 2.5 & (1) 1.3 & (2) 2.5 & (7) 8.8 & (1) 1.3 \\
\hline Hwoźna & 9 & (1.5) 1.7 & (5) 5.6 & (1) 1.1 & (3) 3.3 & (2) 2.2 & (2) 2.2 \\
\hline Perevoloka $^{a}$ & 30 & (5.5) 1.8 & (12) 4.0 & (5) 1.7 & $?$ & $?$ & (9) 3.0 \\
\hline Łutownia & 14 & (1.5) 1.1 & (3) 2.1 & (3) 2.1 & (9) 6.4 & (5) 3.6 & (3) 2.1 \\
\hline Rudavka & 7 & (2) 2.9 & (3) 4.3 & (2) 2.9 & $?$ & $?$ & (2) 2.9 \\
\hline Orłówka & 8 & (0) 0 & (1) 1.3 & (4) 5.0 & (1) 1.3 & (3) 3.8 & (0) 0 \\
\hline Braszcza & 7 & (0) 0 & (0) 0 & (0) 0 & (3) 4.3 & (3) 4.3 & (0) 0 \\
\hline Medium-sized rivers & $79\left[48^{\mathrm{b}}\right]$ & (24) 3.0 & (50) 6.3 & (7) 0.9 & (30) 6.3 & (18) 3.8 & (31) 3.9 \\
\hline Small rivers & $55\left[17^{\mathrm{b}}\right]$ & (9.5) 1.7 & (21) 3.8 & (8) 1.5 & (5) 2.9 & (9) 5.3 & (13) 2.4 \\
\hline Very small rivers & $36\left[29^{b}\right]$ & (3.5) 1.0 & (7) 1.9 & (9) 2.5 & (13) 4.5 & (11) 3.8 & (5) 1.4 \\
\hline Total & $170\left[94^{\mathrm{b}}\right]$ & (37) 2.2 & (78) 4.6 & (24) 1.4 & (48) 5.1 & (38) 4.0 & (49) 2.9 \\
\hline
\end{tabular}

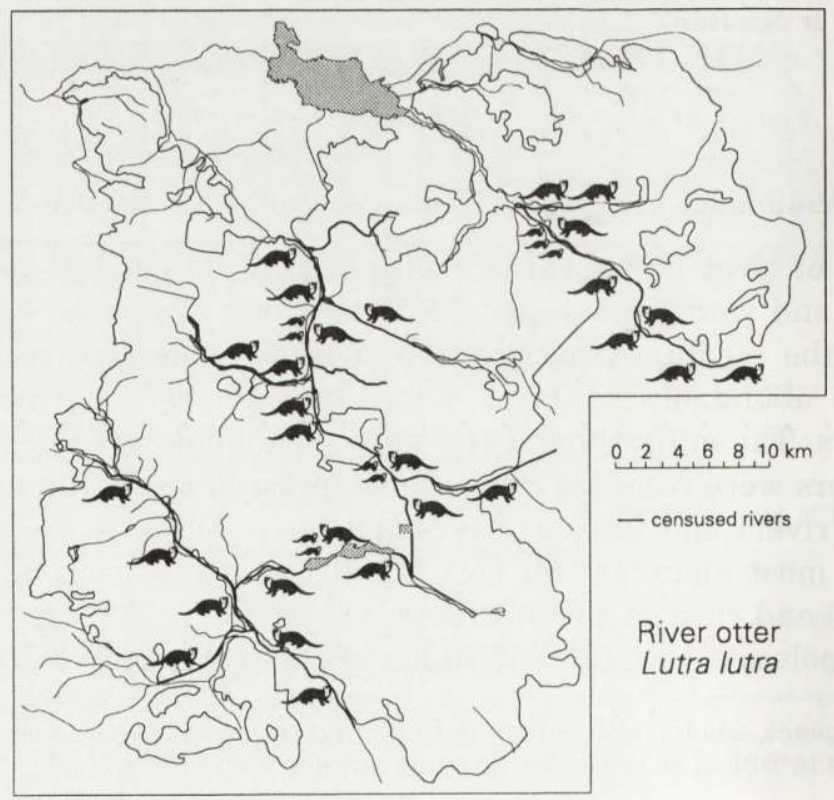



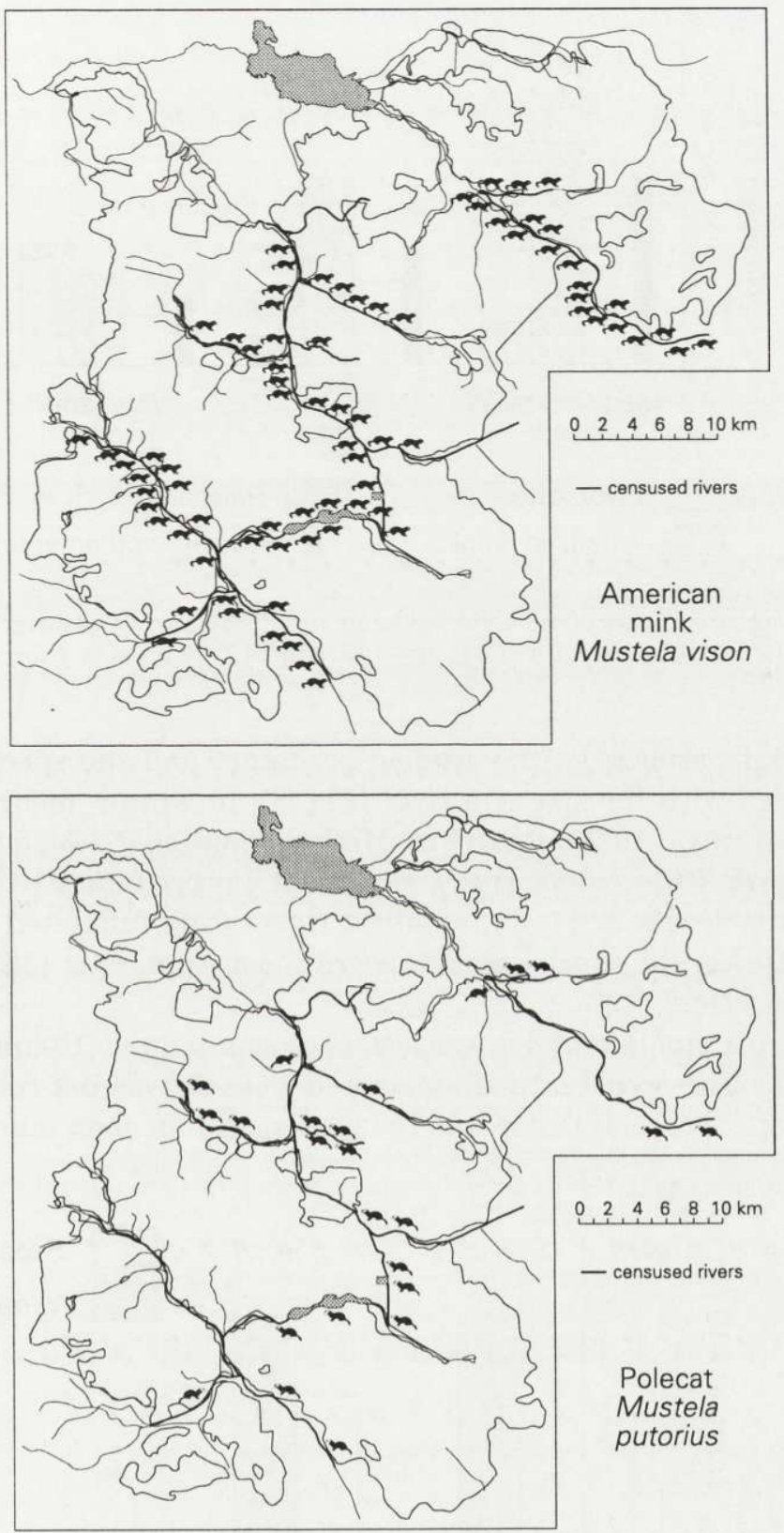

Fig. 2. Distribution of river otters, American mink, and polecats on the censused rivers in Bialowieża Primeval Forest. Each silhouette denotes one animal. In the otter population, family groups are denoted (small silhouettes are young, shown vis-a-vis females). Schematic maps show the borders of the forest, all rivers (censused river are marked by thick lines), and the most important water reservoirs (shaded). For maps of political and administrative divisions, and other details see Fig. 1. 


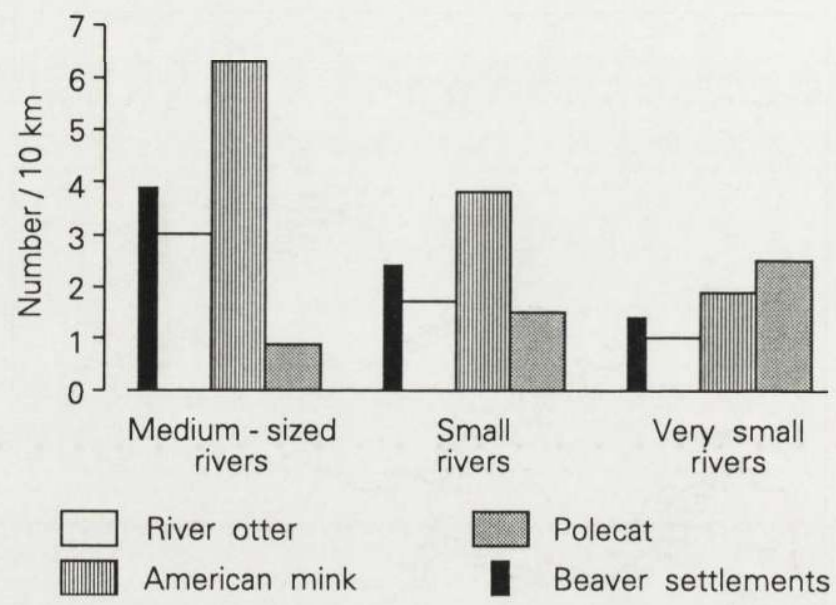

Fig. 3. Winter abundance indices of mustelid predators ( $n$ inds $/ 10 \mathrm{~km}$ of the water course) and beaver settlements ( $n$ settlements $/ 10 \mathrm{~km}$ ) on various size rivers in BPF. See Table 1 for classes of rivers.

Both the total numbers of the studied predators and the species structure of their guild varied with the size of a river (Fig. 3). In winter, medium-sized rivers harboured, on average, $10.2 \mathrm{inds} / 10 \mathrm{~km}$. Mink dominated (62\%), followed by otters $(29 \%)$ and polecats $(9 \%)$. Small rivers sustained 7.0 predators $/ 10 \mathrm{~km}$ (mink $54 \%$, otters $24 \%$, and polecats $22 \%$ ). The smallest rivers were inhabited by, on average, 5.4 predators $/ 10 \mathrm{~km}$, of which polecats were most numerous $(46 \%)$, followed by mink $(35 \%)$ and otters (19\%).

On average, 5.1 stoats and 4.0 weasels were counted per $10-\mathrm{km}$ transect along a river (Table 1). The occurrence of stoats and weasels was not related to the size of river. To stoats, a crucial factor was the presence of an open marshy flood plain.

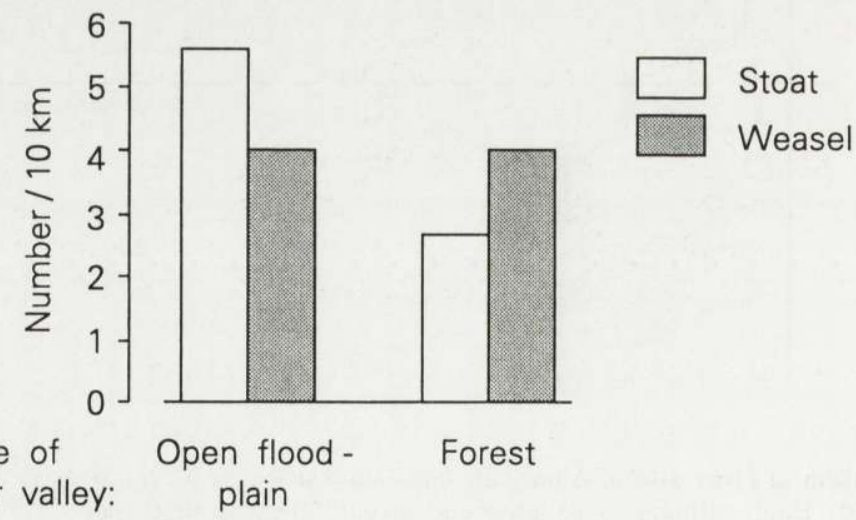

Fig. 4. Winter abundance indices of stoats and weasels ( $n$ inds $/ 10 \mathrm{~km}$ of the river bank) along rivers in $\mathrm{BPF}$ in relation to the type of river valley (open flood-plain marsh or forest). 


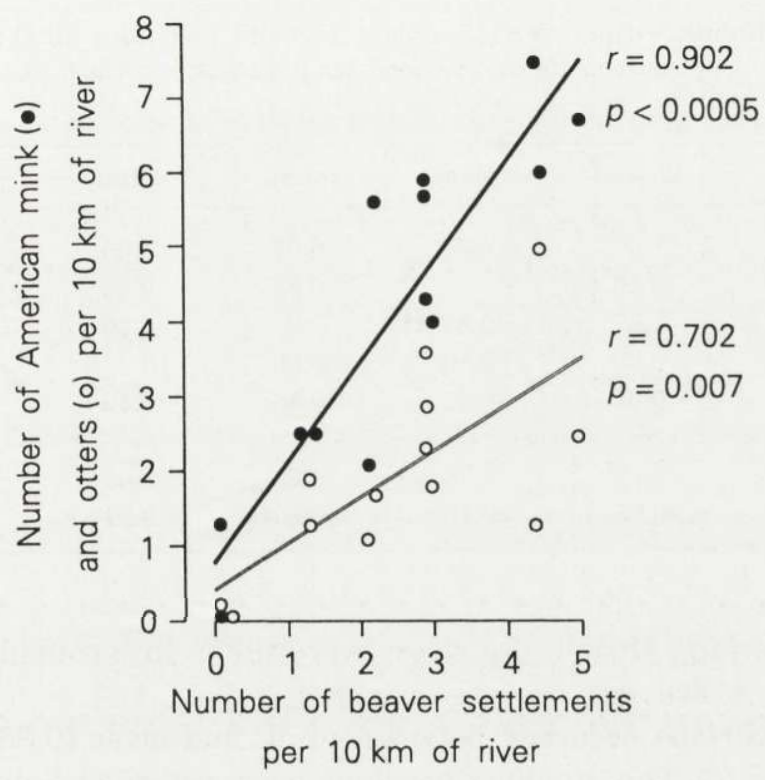

Fig. 5. Correlations between abundance of beaver settlements and numbers of American mink and otter on rivers in BPF. Each point denotes one censused stretch of river (see Table 1).

They were twice as common along rivers with open flood plains as along rivers with forested valleys (Fig. 4). Weasels were equally abundant in both types of habitats.

The larger the river, the more abundant were beaver settlements (Table 1, Fig. 3). On the smallest rivers which occasionally dry out in summer (Orłówka, Braszcza) beavers did not settle. Since the presence of beaver constructions on a river may improve the habitat for mustelids which catch prey in water, we checked whether high numbers of beavers favoured the occurrence of such predators. There was a strong positive correlation between the occurrence of beaver settlements and those of mink and otters (Fig. 5). In the case of mink (but not otters), the relationship was manifest also within each class of river size (see Table 1). This indicates that it was actually the beaver numbers (and not only the increasing size of a river) that was conducive to higher abundance of mink. Abundance of polecats did not correlate with that of beaver $(r=-0.313, n=13, p=0.3)$.

Habitat niche overlaps among mustelid predators inhabiting river valleys

Habitat niche overlaps (index $\alpha$; Pianka 1973) were calculated for five species of mustelid predators according to the formula:

$$
\alpha_{i j}=\left(\Sigma p_{i a} \times p_{j a}\right) \times\left[\left(\Sigma p_{i a}{ }^{2}\right) \times\left(\Sigma p_{j a}{ }^{2}\right)\right]^{-1 / 2}
$$

where $p_{i a}$ - density of $i$ th predator recorded on $a$ th river expressed as percentage of summed indices of abundance on all censused rivers; $\alpha$ varies from 0 (no overlap) 
Table 2. Habitat niche overlaps among mustelid predators inhabiting river valleys in BPF. Pianka's index $\alpha$ varies from 0 (exclusive niches) to 1 (complete overlap of niches).

\begin{tabular}{lccccc}
\hline Species & Weasel & Stoat & Mink & Otter & Polecat \\
\hline Weasel &. & 0.76 & 0.67 & 0.65 & 0.67 \\
Stoat & 0.76 &. & 0.88 & 0.80 & 0.51 \\
Mink & 0.67 & 0.88 &. & 0.86 & 0.46 \\
Otter & 0.65 & 0.80 & 0.86 &. & 0.40 \\
Polecat & 0.67 & 0.51 & 0.46 & 0.40 &. \\
Mean $\alpha$ & 0.69 & 0.74 & 0.72 & 0.68 & 0.51 \\
(SD) & $(0.05)$ & $(0.16)$ & $(0.20)$ & $(0.21)$ & $(0.12)$ \\
\hline
\end{tabular}

to 1 (complete overlap). Only those rivers were taken into consideration on which all 5 species were surveyed.

The highest overlaps occurred between mink and otter (0.86), and mink and stoat (0.88) (Table 2). The smallest overlaps were recorded between polecat and otter, and polecat and mink. Stoat and American mink had the highest mean overlaps, whereas the polecat had the smallest one (Table 2). Indices $\alpha$ calculated for three species (otter, mink, polecat) in all rivers were somewhat higher but showed the same pattern. The biggest overlap was found between otter and mink (0.90); much lower overlaps were recorded between polecat and otter (0.56), and polecat and mink (0.59).

\section{Population size of the censused predators and beavers in BPF}

We have surveyed about $85 \%$ of the total length of medium-sized rivers, about $75 \%$ of the small rivers, and $75 \%$ of very small rivers. Thus, after correcting for the length of noncensused rivers, we estimated the otter population in BPF as about 45 individuals ( 3.1 otters $/ 100 \mathrm{~km}^{2}$ ), and that of American mink as about 95 individuals $\left(6.6 \mathrm{mink} / 100 \mathrm{~km}^{2}\right)$. We cannot estimate the population size of polecats, which inhabit canals and bog forests as well as river valleys. In the pristine forests of Białowieża National Park (including Orłówka river), Jędrzejewski and Jędrzejewska (1993) reported $4-5$ polecats $/ 10 \mathrm{~km}^{2}$.

Density of stoats in the oldgrowth forests of BNP was 2 inds $/ 10 \mathrm{~km}^{2}$ (Jędrzejewski and Jędrzejewska 1993). We assessed (from a 1:25 000 map) the area of open river valleys of Leśna (average width of open valley $300 \mathrm{~m}$ ), Narewka (250 m), Łutownia $(150 \mathrm{~m})$, and Hwoźna $(100 \mathrm{~m})$, and estimated, on average, 27.3 stoats per $10 \mathrm{~km}^{2}$ of the open flood-plain valley. This figure is most likely an overestimate, since stoats recorded in the open marsh (especially in the narrow valleys) could have penetrated the adjacent forests. Nonetheless, it shows that stoats are predominantly concentrated along the rivers. 
Indices of weasel abundance ( $n$ weasels $/ 10 \mathrm{~km}$ of the river bank) were compared to the results of winter surveys of weasels on transects in the forests of BNP (N-S transects, Fig. 5 in Jędrzejewski et al. 1995). In 1985-1992, in the forests, from 2.1 to 7.2 weasels $/ 10 \mathrm{~km}$ of the transect were recorded in various years, which corresponded to the densities of 5.2 to 27.3 (on average 18.4 ) weasels $/ 10 \mathrm{~km}^{2}$. From the regression of both indices $\left(Y=-2.68+4.31 X, n=6\right.$ winters, $\left.R^{2}=0.98\right)$, we estimated that densities of weasels in river valleys might have varied from 2.9 to 35.2 inds $/ 10 \mathrm{~km}^{2}$ (on average $16.2 \mathrm{inds} / 10 \mathrm{~km}^{2}$ ). Thus, they were similar in open valleys and in forests.

After correcting for the length of noncensused rivers, we assessed that about 60 beaver settlements were located in the whole BPF $\left(4.1\right.$ settlements $\left./ 100 \mathrm{~km}^{2}\right)$. Żurowski and Kasperczyk (1986) showed that in a stabilised population of beavers in NE Poland, there were on average 3.7 individuals per settlement (lodge or burrow system). It would mean that in BPF, there were about 220 beavers, ie 15.2 inds $/ 100 \mathrm{~km}^{2}$.

\section{Discussion}

Mechanisms of habitat preferences and niche repartition in mustelid predators on natural rivers in temperate forests of lowland Europe

In southern Sweden, female river otters stretched their ranges along 10-12 $\mathrm{km}$ of river, and males on 10-21 km (Erlinge 1967). Male American mink utilised 1-5 km, and females about $2 \mathrm{~km}$ (Gerell 1970). In Białowieża National Park, male European polecats occupied 1-3 km of river, and females 0.6-1.6 km (Brzeziński et al. 1992). In these 3 species of predators, the ranges overlapped, and those of males and females may overlap completely.

Sidorovich (1991) censused otters in the primeval habitats of Berezinskii Reserve in NE Belarus. The highest densities (on average 4.9 otters $/ 10 \mathrm{~km}$, range 4.3-5.5) were recorded on the large Berezina river (width of river bed $20-40 \mathrm{~m}$, depth 1.5-2 m). On eleven smaller rivers (tributaries of Berezina, 1-8 m wide, 0.3-1.6 m deep), densities of otters varied from 1.3 to 3.0 per $10 \mathrm{~km}$ (mean 2.1). In similar habitats of the natural rivers in the protected Naliboki Forest, otter densities were 1.7-4.0 inds/10 km of medium- and small-sized rivers (Sidorovich 1992a). Therefore, the data from Białowieża Primeval Forest (from 1.0 otter $/ 10 \mathrm{~km}$ of very small rivers to 2.9 on medium-sized ones) corresponded very well with the general pattern of otter abundance on woodland rivers.

Despite low numbers of otters on small and very small rivers, this kind of habitat is of tremendous importance for a wide scale functioning of otter population, due to the total length of small rivers exceeding that of larger ones. In Białowieża, the largest river, Narew, harboured about $25 \%$ of the otter population, and the remaining three quarters dwelled upon smaller rivers. In the Berezinskiï Reserve (Sidorovich 1991), the Berezina river $(110 \mathrm{~km})$ harboured $57 \%$ of the otter 
population, whereas the censused parts of smaller rivers (totally $201 \mathrm{~km}$ ) supported the remaining $43 \%$.

The distribution and densities of otters on lowland rivers in the temperate forests of Europe are shaped by the abundance of two food resources: fish and amphibians. Consumption of fish by otters grows with the size of the river, whereas amphibians dominate otter diet on small rivers. On the Berezina river, fish made up $84 \%$ of otters' food biomass and amphibians $10 \%$. On small-sized tributaries of Berezina, fish comprised $76 \%$ of food biomass taken by otters and amphibians 12\% (Sidorovich 1991). On small rivers, the Narewka and Hwoźna, in Białowieża Primeval Forest, fish constituted $41 \%$ of otters' food biomass, and amphibians 53\% (Brzeziński et al. 1993).

In BPF, American mink occurred in higher densities on larger river than on smaller ones. Sidorovich (1988) synthesized the results of his surveys of American mink on small rivers in the protected areas of the Berezinskii Reserve, Naliboki Forest, and the forests in the Smolevichi, Uzda, Usachi, and Gorodok regions (NE Belarus), where mink populations were exploited by hunters. Mean densities were from 2.3 to $10.9 \mathrm{mink} / 10 \mathrm{~km}$ of river. In Southern Sweden, Gerell (1970) captured 10 mink on an $8-\mathrm{km}$ stretch of the stream $(12.5 \mathrm{mink} / 10 \mathrm{~km})$. Thus, the mean abundance of $4.6 \mathrm{mink} / 10 \mathrm{~km}$ of river in Białowieża Forest are within the range of variation reported from other regions.

As regards its feeding habits, American mink is a generalist capable of utilising fish, amphibians, rodents and birds (Brzeziński and Żurowski 1992, Sidorovich 1992b). In Białowieża Primeval Forest, mink foraged on fish and amphibians (40\% and $32 \%$ of food biomass, respectively) in spring and summer, and shifted to frogs and rodents $(51 \%$ and $32 \%$ ) in autumn and winter (W. Jędrzejewski and V. E. Sidorovich, unpubl.).

Has American mink overtaken a vacant niche after the extinction of European mink in Białowieża? In Spain, Palazon and Ruiz-Olmo (1993) studied European mink by telemetry and found that males occupied $3-8 \mathrm{~km}$ of the river, and a female about $4 \mathrm{~km}$. Sidorovich and Kozulin (1994) reported that in a relatively stable population of European mink on the upper course of Lovat river (NE Belarus), the densities were $4-10$ inds $/ 10 \mathrm{~km}$ of the river. In a declining populations in the Tver region (W Russia), only 0.8 to $2.4 \mathrm{mink} / 10 \mathrm{~km}$ were found (Sidorovich and Kozulin 1994). In its feeding habits (natural habitats on Lovat river, NE Belarus), European mink relied on amphibians (47\% of prey biomass), small mammals (27\%), fish (13\%), birds (11\%), and insects (2\%). Its diet was very similar to that of the American mink inhabiting the same region; the mean similarity index was 75\% (Sidorovich 1992b). Therefore, ecologically, American mink substituted for the native species which had become extinct in Białowieża long before the spontaneous colonization of the terrain by American mink.

In the natural habitats, polecats are connected with small rivers and marshes. On a total of $1154 \mathrm{~km}$ of snowtracking transects in the regions of Petersburg, Novgorod, and Pskov (NW Russia), Danilov and Rusakov (1969) found 50\% of 
recorded polecats along small rivers, $7 \%$ on marshes, $18 \%$ in human settlements, $20 \%$ in forests, forest-field ecotones and clearcuts, and 5\% on meadows. Snowtracking conducted in the pristine forests of Białowieża Primeval Forest showed that polecats strongly preferred river-side flood plain forests and bog alderwoods (Jędrzejewski et al. 1993). In BNP, the winter diet of polecats consisted of amphibians (70-98\% of biomass) and small mammals (2-30\%) (Jędrzejewski et al. 1993). On the Lovat river (NE Belarus), polecats relied on small mammals (65\% of food biomass) and amphibians (22\%) (Sidorovich 1992b). A shift in polecats' diet between frogs and small mammals, caused by seasonal changes in the availability of these two main resources, was observed by Sidorovich (1992b) in Belarus and by Lodé (1993) in France.

Stoats and weasels are terrestrial predators and they do not forage in water. In BPF, stoats preferred open marshes in the river valleys, which are inhabited by the root vole Microtus oeconomus (Jędrzejewski et al. 1989). Vaisfeld (1972), who studied stoats in the taiga forests in NW Russia, found a strong preference of these predators for open marshy river valleys. Mean home range of stoats, as revealed by snowtracking, covered $0.57 \mathrm{~km}^{2}$ (Vaisfeld 1972).

Beavers attain very high densities in habitats rich in water, eg over 18 settlements $/ 100 \mathrm{~km}^{2}$ (67 beavers/100 $\mathrm{km}^{2}$ ) in Suwałki Lakeland, NE Poland (Żurowski and Kasperczyk 1986). Positive correlation between the numbers of beaver sites and densities of mink and otters has commonly been observed in Belarus (Sidorovich 1992c). Mink and otter profit from ice-free access to water in winter around beaver lodges and burrows and they use lodges as marking places. Mink dens were found in many of the censused beaver lodges in Białowieża Forest. Similar coexistence of beavers and mink was reported by Żurowski and Kammler (1987) from NE Poland.

\section{Drainage and land reclamation - their effects on mustelid predators and beavers}

In the last century in Poland and Belarus, large scale amelioration, drainage and land reclamation projects have turned most of the natural small rivers into canals, and marshy valleys into dry land. Sidorovich (1988) synthesised his extensive surveys of otter and mink on small rivers and water courses in NE Belarus, and reported that the lowest densities were on large drainage canals in the farmlands (on average 0.7 otter and $1.1 \mathrm{mink} / 10 \mathrm{~km}$ ). Otters were also rare on canalised small rivers in the forests (mean 1.1 otters $/ 10 \mathrm{~km}$ ). In the Pruzhana forest (adjoining the Białowieża Primeval Forest from NE), the large net of canals (total length $160 \mathrm{~km}$ ) at the sources of the Yaselda river harboured on average 0.6 otters, $1.1 \mathrm{mink}$, and 0.5 beaver settlements per $10 \mathrm{~km}$ (Sidorovich 1992c). The canalised Yaselda river $(32 \mathrm{~km}$ ) was inhabited by, on average, 0.6 otter, 1.9 mink, 0.6 polecats, and 0.6 beaver settlements per $10 \mathrm{~km}$ (V. E. Sidorovich, unpubl.).

However, construction of ponds and water reservoirs improved the habitat for mustelid predators and beavers. In Pruzhana Forest, the Selec water reservoir and adjoining fish ponds (about $34 \mathrm{~km}^{2}$ ) sustained on average 2.3 otters, 11.8 
mink, and 2.6 beaver settlements per $10 \mathrm{~km}^{2}$ of water surface (Sidorovich 1992c). Densities of amphibians around Selec and adjoining fish ponds were quite high (mean 158 inds/ha) and, obviously, the abundance of fish was high (Pikulik et al. 1987).

The reason for much lower densities of mustelids on canals and canalised small rivers is not only the lack of suitable den sites, but also - and perhaps predominantly - the dramatic decline of food resources. The densities of amphibians were 5-fold lower in the drained terrain (53 inds/ha on Trukhanovichi canal system, Pruzhana Forest) in comparison to the natural flood plain marshes (on average 248 inds/ha in Borki along the Narew river) (Pikulik et al. 1987).

Acknowledgements: The study was supported by the grant for Polish - Belarussian cooperation and exchange from the Polish Academy of Sciences, budget of the Mammal Research Institute PAS, and grant KBN 4441691 02. We thank Karol Zub and Edyta Bajko for preparing maps and figures. Critical comments by three anonymous reviewers helped us to improve this paper.

\section{References}

Brzeziński M., Jędrzejewski W. and Jędrzejewska B. 1992. Winter home ranges and movements of polecats Mustela putorius in Białowieża Primeval Forest, Poland. Acta Theriologica 37: 181-191.

Brzeziński M., Jędrzejewski W. and Jędrzejewska B. 1993. Diet of otters (Lutra lutra) inhabiting small rivers in the Białowieża National Park, eastern Poland. Journal of Zoology, London 230 $495-501$.

Brzeziński M. and Żurowski W. 1992. Spring diet of the American mink Mustela vison in the Mazurian and Brodnica Lakelands, northern Poland. Acta Theriologica 37: 193-198.

Danilov P. I. and Rusakov O. S. 1969. Peculiarities of the ecology of Mustela putorius in North-West districts of the European part of the USSR. Zoologicheskiï Zhurnal 48: 1383-1394. [In Russian with English summary]

Dunstone N. and Birks J. D. S. 1987. The feeding ecology of mink (Mustela vison) in coastal habitat. Journal of Zoology, London 212: 69-83.

Erlinge S. 1967. Home range of the otter Lutra lutra L. in Southern Sweden. Oikos 18: 186-209.

Faliński J. B. 1986. Vegetation dynamics in temperate lowland primeval forests. Dr W. Junk Publishers, Dordrecht: 1-537.

Gerell R. 1970. Home ranges and movements of the mink Mustela vison Schreber in southern Sweden Oikos 21: $160-173$.

Görner M. and Hackethal H. 1988. Säugetiere Europeas. Neumann Verlag, Leipzig - Radebeul: $1-371$.

Goszczyński J. 1977. Connections between predatory birds and mammals and their prey. Acta Theriologica 22: 399-430.

Jędrzejewski W. and Jędrzejewska B. 1993. Predation on rodents in Białowieża primeval forest, Poland. Ecography 16: 47-64.

Jędrzejewski W., Jędrzejewska B. and Brzeziński M. 1993. Winter habitat selection and feeding habits of polecats (Mustela putorius) in the Białowieża National Park, Poland. Zeitschrift für Säugetierkunde 58: 75-83.

Jędrzejewski W., Jędrzejewska B. and Szymura A. 1989. Food niche overlaps in a winter community of predators in the Białowieża Primeval Forest, Poland. Acta Theriologica 34: 487-496.

Jędrzejewski W., Jędrzejewska B. and Szymura L. 1995. Weasel population response, home range, and predation on rodents in a deciduous forest in Poland. Ecology 76: 179-195. 
Kruuk H. and Moorhouse A. 1990. Seasonal and spatial differences in food selection by otters (Lutra lutra) in Shetland. Journal of Zoology, London 221: 621-637.

Lodé T. 1993. Diet composition and habitat use of sympatric polecat and American mink in western France. Acta Theriologica 38: 161-166.

Maran T. 1990. Conservation of the European mink in Estonia. Mustelid and Viverrid Conservation 2: 12 .

Palazon S. and Ruiz-Olmo J. 1993. Preliminary data on the use of space and activity of the European mink (Mustela lutreola) as revealed by radio-tracking. Small Carnivore Conservation 8: 6-8.

Pianka E. R. 1973. The structure of lizard communties. Annual Review of Ecology and Systematics 4: $53-74$.

Pikulik M. M., Kosov S. V., Drobenkov S. M., Letenskiï A. A. and Khandogiï A. V. 1987. [Evaluation of the effects of drainage of lowland marshes on amphibian and reptile populations (on the example of Belarussian Polese, the watershed of Yaselda and Narev rivers)]. Viniti, Minsk: 1-32. [In Russian]

Pikulik M. M. and Sidorovich V. E. 1991. [Evaluation of structural-functional relationships between semiaquatic predators and amphibians of Belarus]. Ekologiya 6: 28-36. [In Russian]

Pucek Z. (ed) 1984. Klucz do oznaczania ssaków Polski. Państwowe Wydawnictwo Naukowe, Warszawa: 1-384. [In Polish]

Pucek Z. and Raczyński J. (eds) 1983. Atlas of Polish mammals. PWN - Polish Scientific Publishers, Warszawa. 1-188+1-183.

Saint-Girons M.-C. 1991. Le vison sauvage (Mustela lutreola) en Europe. Council of Europe. Colloqium Sauvegarde de la Nature 54: 1-41.

Sidorovich V. E. 1988. [Ecological analysis of the abundance of semiaquatic predators on small rivers in Belarus]. Zapovedniki Belorussii 12: 123-126. [In Russian]

Sidorovich V. E. 1991. [Otter in the Berezinskiï Reserve]. Zapovedniki Belorussii 14: 143-150. [In Russian]

Sidorovich V. E. 1992a. [Structure of otter population in Belarus]. Byulleten Moskovskogo Obshchestva Ispytateleï Prirody, Otdel Biologicheskiï 97(6): 43-51. [In Russian]

Sidorovich V. E. 1992b. Comparative analysis of the diets of European mink (Mustela lutreola), American mink (M. vison), and Polecat (M. putorius) in Byelorussia. Small Carnivore Conservation 6: $2-4$.

Sidorovich V. E. 1992c. [Influence of amelioration works on densities of semiaquatic mammals in Yaselda river basin]. Vesci Akademii Navuk Belarusi, Seriya Biyalagichnykh Navuk 2(1992): 48-52. [In Belarussian]

Sidorovich V. E. 1994. How to identify the tracks of the European mink (Mustela lutreola), the American mink (M. vison) and the Polecats (M. putorius) on waterbodies. Small Carnivore Conservation 10: 8-9.

Sidorovich V. E. and Kozulin A. V. 1994. Preliminary data on the status of the European mink's (Mustela lutreola) abundance in the centre of the eastern part of its present range. Small Carnivore Conservation 10: 10-11.

Tumanov I. L. and Zverev E. L. 1986. Current spread and abundance of the European mink (Mustela lutreola) in the USSR. Zoologicheskii Zhurnal 65(3): 426-435. [In Russian with English summary]

Vaisfeld M. A. 1972. A contribution to the ecology of ermine during the cold season in the European north. Zoologicheskii Zhurnal 60: 1705-1714. [In Russian with English summary]

Weber D. 1989. The diet of polecats (Mustela putorius) in Switzerland. Zeitschrift für Säugetierkunde 54: $157-171$.

Żurowski W. 1979. Preliminary results of European beaver reintroduction in the tributary stream of the Vistula river. Acta Theriologica 24: 81-87.

Żurowski W. and Kammler J. 1987. American mink (Mustela vison Schreber, 1777) in beaver's sites. Przegląd zoologiczny 31: 513-521. [In Polish with English summary] 
Żurowski W. and Kasperczyk B. 1986. Characteristics of a European beaver population in the Suwałki Lakeland. Acta Theriologica 31: 311-325.

Żurowski W. and Kasperczyk B. 1988. Effects of reintroduction of European beaver in the Lowlands of the Vistula Basin. Acta Theriologica 33: 325-338.

Received 5 May 1995, accepted 16 March 1996. 